\title{
Beyond the use of Code Mixing by Social Media Influencers in Instagram
}

\author{
Bejo Sutrisno $^{1 *}$, Yessika Ariesta ${ }^{2}$ \\ ${ }^{1}$ Sekolah Tinggi Bahasa Asing - IEC Jakarta, Indonesia \\ ${ }^{2}$ Sekolah Tinggi Bahasa Asing - IEC Bekasi, Indonesia \\ Corresponding Author: bejo@stibaiec-jakarta.ac.id, yessikaariesta@gmail.com
}

\section{ARTICLE INFO}

\section{Article history}

Received: September 17, 2019

Accepted: November 11, 2019

Published: December 31, 2019

Volume: 10 Issue: 6

Advance access: December, 2019

Conflicts of interest: None

Funding: None

\section{Key words:}

Code-mixing,

Social media,

Influencers,

Instagram,

Indonesian Followers

\begin{abstract}
The purpose of this study is to analyse code-mixing used by social media influencers in Instagram. The method of this research is qualitative method and observation is uded to find the posts of influencers where they use code-mixing. Questioning to the influencers about the reasons they often use code-mixing through Instagram direct message or email are also done. The writer decided that the two familiar influencers from public figures are the main samples of this research. The result from this research is that the influencers use code mixing because they want Indonesian people to develop themselves by mastering English language and they want to give example to people, especially their followers that English can be fun and everyone can practice English. Being habit is also one of the reasons that they like to use code mixing. The Influencers use code-mixing in instagram in certain time, such as lunch time and after office hours, because those are the active time for them and their followers online in Instagram. It is evident that the use of code-mixing by the influencers arouse the followers interested and motivated to sharpen their English language and it could be as one of the parts in practicing the followers' English through social media. It then becomes one of the way to learn more a foreign language through social media.
\end{abstract}

\section{INTRODUCTION}

Language is a method of human communication, either spoken or written, consisting of the use of words in a structured and conventional way. There are two kinds of language, formal language and informal language. Formal language is a kind of language that is used in more formal and serious situations. Informal language is a kind of language that is used in more relaxed and casual situations.

Establishing why language is important, Henry Sweet (2007), an English phonetician and language scholar, stated that language is the expression of ideas by means of speech sounds combined into sentences, this combination answering to that of ideas into thoughts. The American linguist Bernard Bloch and George L. Trager (1942) define that a language is a system of arbitrary vocal symbols by means of which a social group cooperates. This definition point out that language is a system. According to a system, sounds join to form words. For example, the combination "b-o-o-k" join to form a meaningful word. The combinations "k-o-o-b" or "o-o-b-k" do not. Meanwhile, Shaghi (2013) mentioned that words join to form sentences, for example : "A football is a game of wonderful entertainments" is acceptable, but a string of words like "A game is of a football wonderful entertainments" is not. In this sense, language is considered a system of systems.
Geofrey Leech (1974) highlighted that language has five functions. First, informational; it is used to give information. Second, expressive; it can be used to express feelings and attitudes. Third, directive; such as commands and requests. Fourth, aesthetic; it is used for the sake of the linguistic artefact. And the last is phatic; it is used to keep social relationships in good repair".

Based on what the writer's observation, almost every person has more than one language ability. We call it bilingualism and multilingualism. In every language, there is code; a system of words, letters, figures, or other symbols substituted for other words, letters, etc. There are some types of codes, one of them is code-mixing. Code mixing is the mixing of two or more languages varieties in speech. For example, English/Indonesian code mixing : "I mean, ganti ke kalimat lain." or "By the way, nanti siang kita lunch apa?"

A lot of people use code mixing in their comminocation. Even they are not realized if they often use code mixing. There must be some reasons they use code mixing. One of the reasons is that the factor of social media. Nowadays, It cannot be denied that people spend more time with social media and they can enjoy everything through social media. The fact that social media has influenced the people to use code-mixing in their communicaton as well as the social 
media influencers have significant roles especially in one of the most-seen social media like Instagram, as the public figures for the followers.

As an illustration, the writer presents example in some caption and or comments which describe the reality of the use of code mixing in social media especially Instagram, such as : (1) Tidak terasa sudah setahun. Happy Anniversary; (2) Review-nya bakal aku post malam ini ya, guys; (3) Jujur aku sih udah punya feeling kalau akan jadi seperti ini; (4) Saturday Night ini enaknya kemana ya?; (5) Jangan lupa untuk subscribe channel Youtube aku ya.

Based on the examples above, the writer can say that the linguistic form which is commonly used by Instagram users is "word" because this is the easiest form. Then, the present result is in line with Suwito (1983) who divided code mixing into some forms:

1. Word insertion - The insertion of words here means inserting words from another language into a dominant language that used in a conversation.

2. Phrase insertion - A phrase is a group of words without a verb, especially one that forms part of a sentence. Phrase insertion here a sequence of words, which used to refer to a sequence of words functioning as a single unit.

3. Idiom or expression insertion - Idiom is phrase or sentence whose meaning is not clear from the meaning of its individual words and which must be learnt as a whole unit. While expression is a word or phrase or term from particular field. It means inserting an idiom or a term from particular field from another language into the conversation.

4. Hybrid insertion - Literally, hybrid is a thing made by combining two different elements. In this case, hybrid is the combination between native and foreign form. Such as, combine prefix from one language with a word from another language.

5. Reduplication insertion - Reduplication is a repetition of word.

The explanation above shows the use of code mixing between Bahasa Indonesia and English. For some people, this is very common and they support the use of code mixing because they think language knowledge is important for their social relationship and career. But some people also think that they should not use code mixing as a symbol of their appreciation to their mother tongue, in this case, Bahasa Indonesia. Instagram is chosen as the source of data because it is one of the social media with largest amount of users. The topic is important to be analysed because followers are sometimes not aware of the language they use and why they choose to use code mixing while some people only understand one language. Based on that point of view, the use of code mixing in Instagram by some influencers gets more attention to be observed.

The aim of this paper, therefore, is to identify the use of code-mixing by the influencers which could influence Indonesian followers in studying English as a foreign language which Shabir et al. (2014), believed that social media influences the youth and females included.

Based on the reasons above, the objectives are to find out the reasons that the influencers use code mixing and and to know when the influencers use code mixing.

\section{Literature Review}

Code mixing has been discussed by a great number of authors in literature. For example, research has provided evidence for lexical items and grammatical factors have been the proof that are often occurred in a language. Muysken (2000) stated that all cases where lexical items and grammatical features from two languages appear in one sentence. In addition, Nababan said that "code mixing is found mainly in informal interactions. In formal situation, the speaker tends to mix it because there is no exact idiom in that language, so it is necessary to use words or idioms from other language".

Subsequently, Wardaugh (1986) states that code mixing occurs when conversants use both languages together to the extent that they change from one language to the other in the course of single utterance and code mixing occurs when during conversation, speakers use both languages together to the extent that they shift from one language to the other in the course of the single utterance (Wardaugh, 2011). It means that the conversants just change some of elements in their utterance. Code mixing takes place without change of topic and can involve various levels of language, e.g., morphology and lexical items. In code mixing, pieces of one language are used while a speaker is basically using another language (Lucas, 1990).

Meanwhile, Muysken (2000:109) and Hoffman (1991:104) belive that the term code mixing is referred to all cases where lexical item and grammatical features from two languages appear in one sentence. And in code mixing, pieces of one language are used while a speaker is basically using another language. It means that code mixing is mainly found in informal interactions and it occurs when the conversants use both languages together in term of that all cases about lexical and grammatical features are the act of switching languages.

\section{Types of Code Mixing}

Hoffman (1991:104) mentions three types of code mixing based on the juncture or the scope of switching where languages take place. Those are intra-sentential code mixing, intra lexical code mixing, and involving a change of pronunciation. Each type will be describing bellow:

\section{Intra-sentential code mixing}

This kind of code mixing occurs within a phrase, a clause or a sentence boundary, as when a French-English bilingual says: "I started going like this. Y luego decla (and then he said), look at the smoke coming out my fingers." Another example is from Wardaugh "Estaba training Para pelar" : "He was training to fight." (Wardaugh:1986).

Siregar (1996:50) stated that intra-sentential mixing may range from the alternation of single words or phrases to clauses within a single sentence or utterance.

The follwoings are the examples of code mixing of English inserted in Bahasa Indonesia:

- Aku benar-benar confused soal masalah ini. (Confused as code mixing of word in the sentence)

Maaf kemarin aku gak hadir di acaramu. I have important meeting. (I have important meeting as code mixing of clause) 
- $\quad$ Tolong difollow up terus ke pihak bersangkutan ya. (follow up as code mixing of phrase in the sentence) The sentences form of code mixing are as follow :

a. Declarative. In declarative, the subject and predicate have normal word order. The sentence ends with period in writing and drop in pitch in speech. For example : "I want to buy ice cream now. Lagi pengen banget makan itu."

b. Interrogative. Interrogative includes yes/no question, WH (what, when, why, where, when) question, and subject question. For example : "Sin, kamu mau es krim rasa apa? Chocolate or vanilla?"

c. Imperative. Imperative sentences usually contain the imperative of a verb. The imperatives used in request which according to circumstances may range from brusque commands to humble entreaties, the tone generally serving as key to the exact meaning. For example

: "Hurry up! Kita udah telat nih"

Based on the examples above, it can be seen that those are code mixing sentences with single word, single clause, and single phrase.

\section{Intra-lexical code mixing}

This kind of code mixing which occurs within a word boundary involving a change in pronunciation. For example, when Spanish/ Latino people say an English word but modify it to Spanish phological structure like in "sapper" (English Shop with the Panjabi plural ending) or "Kuenjoy" (English enjoy with the Swahili prefix Ku, meaning 'to').

\section{Involving a change of pronunciation}

This kind of code mixing occurs at the phonological level, as when Indonesian people say an English word, but modify it to Indonesian phonological structure. For instance, the word 'strawberry' is said to be 'strawberry' by Indonesian people.

\section{The Factors that Cause Code Mixing}

Kim (2006) believes that there are some factors why people use code mixing. Some reasons are:

1. Bilingualism

It cannot be avoided that the ability to speak more than one language is a basic factor of code mixing. Most of the world's population is bilingual or multilingual.

2. Speaker and partner speaking

Communication is the process of expressing ideas between two participants of conversation. Speaker needs partner speaking to communicate and code mixing could appear if both use and understand it well.

3. Social community

An individual lives and cooperates in one community either in monolingual or bilingual community. Now most communities are bilingual that use two languages in their interactions. In this case, an individual will be influenced by social community directly.

4. Situation

Usually code mixing occurs in relax or informal situation. This situation is closer with daily conversation and for writer, it is also described as their habitual communication.

5. Vocabulary

There is not an appropriate word or when there is a lack of vocabulary in one language. The inability to find an appropriate word or expression in one language makes people change the word or phrase from one to another language and it can be combined together.

6. Prestige

Globalization era has led people to be able to speak more than one language, especially English. For many young people code mixing becomes their own style which is hoped to be modern and educational one. They mix language because of prestige.

\section{Social Media}

According to Akram and Kumar (2017) Social media is an online platform which people use to build social networks or social relations with other people who share similar personal or career interests, activities, backgrounds or real-life connections.

Another opinion, according to Chukwuere and Chuckwuere (2017), that Social media creates channels for connectivity, communication, discussion and interaction among people. The channels provide news and information across genders. Meanwhile the world events of today are impacted by social media as researches prove that $50 \%$ of people on daily basis gets instant news through this channel (Lowisz, 2014).

From the above definitions, it can be concluded that a basic definition of social media is that social media is webbased communication tools that enable people to interact with each other to share and seek for information.

In addition, Safko and Brake (2009) adopt a more generalized approach and propose that social media are activities, practices and behaviours among communities of people who gather online to share information, knowledge, and opinions using conversational media. Conversational media are Webbased applications that make it possible to create and easily transmit content in the form of words, pictures, videos, and audios.

As well as Xiang and Gretzel (2010) attempt the definition social media can be generally understood as internet-based applications that carry consumer generated content which encompasses media impressions created by customers, typically informed by relevant experience, and archived or shared online for easy access by other impressionable customers.

In conclusion, social media is a really convenient and important communicate network for all the people nowadays. It can be used to know friends and keep contact with friends that came from different countries, also to share ideas so quickly so that all the things could develop so fast because people could tell their ideas, and those could be improved immediately. Through it people can also learn new things by watching or reading the things that others share, it is also media to sell things freely which could reduce the expenditure of advertisements. 


\section{Kinds of Social Media}

Among several kinds of social media, here are the list of the top 10 most popular social media sites in 2019 (www.buffer. com, accessed on May 27 $\left.7^{\text {th }}, 2019\right)$ :

1. Facebook - Facebook is a social networking website where users can post comments, share photographs, and post links to news or other interesting content on the web, chat live, and watch short form video (www.lifewire.com, accessed on August 27 $7^{\text {th }}$ 2019).

2. YouTube - Youtube is a video sharing service that allows users to watch videos posted by other users and upload videos of their own (www.techterms.com, accessed on August 27 $7^{\text {th }} 2019$ )

3. WhatsApp - Whatsapp is a cross-platform instant messaging applications that allows iPhone, Blackberry, Android, Windows Phone, and Nokia smartphone users to exchange text, image, video and audio messages for free. (www.techtarget.com, accessed on August 27 $7^{\text {th }}$ 2019)

4. Messenger - Messenger is a mobile app that enables chat, voice and video communications between the social media site's web-based messaging and smartphones (www.techtarget.com , accessed on August 27 $7^{\text {th }}$ 2019).

5. WeChat - WeChat is a mobile text and voice messaging communication service developed by Tencent in China, first released in January 2011. The app is available on Android, iPhone, BlackBerry, Windows Phone platforms (www.whatiswechat.com, accessed on August $27^{\text {th }} 2019$ ).

6. Instagram - Instagram is an online photo sharing service. It allows you to apply different types of photo filters to your pictures with a single click, then share them with others (www.techterms.com , accessed on August $27^{\text {th }} 2019$ )

7. QQ - Like WeChat, QQ offers a bunch of different services, including gaming, music, movies, blogging, and group chat. QQ allows users to publish ads and links to friends (www.linkinfluence.com, accessed on August $\left.27^{\text {th }} 2019\right)$.

8. Tumblr - Tumblr is microblogging platform designed for creative self-expression. It is considered a mindful alternative to Facebook and other social media websites where users blog on a myriad of topics (www.techopedia.com, accessed on August 27 $7^{\text {th }} 2019$ ).

9. Qzone - Ozone is a social media that usually used by businesess to encourage organic and enganging conversation between people (www.digitalzone.in , accessed on August $27^{\text {th }} 2019$ )

10. Tik Tok - Tik Tok is a social media platform for creating, sharing, and discovering short music videos, it is like karaoke for the digital age (www.webwise.ie , accessed on August 27 $7^{\text {th }} 2019$ ).

\section{Instagram}

Instagram is a social networking application made for sharing photos and videos from a smartphone. Similar to Facebook or Twitter, everyone who creates an Instagram account has a profile and a news feed.
When you post a photo or video on Instagram, it will be displayed on your profile. Other users who follow you will see your posts in their own feed. Likewise, you'll see posts from other users whom you choose to follow (www.lifewire. $\underline{\text { com }}$, accessed on May $5^{\text {th }} 2019$ ).

According to Walter and Giolgio (2014), they stated that Instagram is a free, visual content sharing social network, focused on the taking and sharing of photos with friends within a mobile application. The photos are cropped into a universal size, and can be edited by for example adding filters to create different effects. The posted photo appears in the feed of the users who follow the poster, in a reverse chronological order with the newest photo displayed on top. The sharer can tag other users in the photos, tag the place where the photo is taken, and write a caption for the photo which can include hashtags and mention (marked with "\#” and "@”, respectively) to share the photo and categorized the content).

The explanation above is clearly described about the definition of Instagram and how it works. So it can be concluded that Instagram is a social media which people oftenly use. It becomes one of the most popular social media among social media users.

\section{The features of instagram}

Since its launch, Instagram has added many features that benefit marketers - both paid ads features as well as organic posts. Some of the most important Instagram features are:

1) Video Features

You're probably familiar with Instagram Video posts - they're like regular photo posts, except they allow for video up to 60 seconds long. You can add a filter, a caption and tag your location before you share the post. Video posts generate more user engagement than photos on Instagram.

2) Live Video

Live Video is different than Instagram Video because well, it's live. Here's how it works:

a. Followers get a push notification telling them you're going live

b. Followers can comment on or like your Live Video stream in real time

c. The video is gone after you end it (it doesn't save to your account)

3) Stories Features

One of the biggest additions to Instagram as of late is the Stories feature. Stories is similar to Snapchat in that users add clips of video to a story which is viewable for 24 hours before it vanishes. You can view Story content as many times as you want within that 24-hour period. Stories appear as little circles in the top of your followers' feeds. More Stories Features:

a. Video recording up to 15 seconds

b.Image viewing up to 10 seconds

c. Unlimited story additions

d. Direct messaging within Stories

e. Swipe down on the camera screen to unlock photos and videos from your personal camera roll (You can only access content on your camera roll from the last 24 hours) 


\section{Influencer BW}

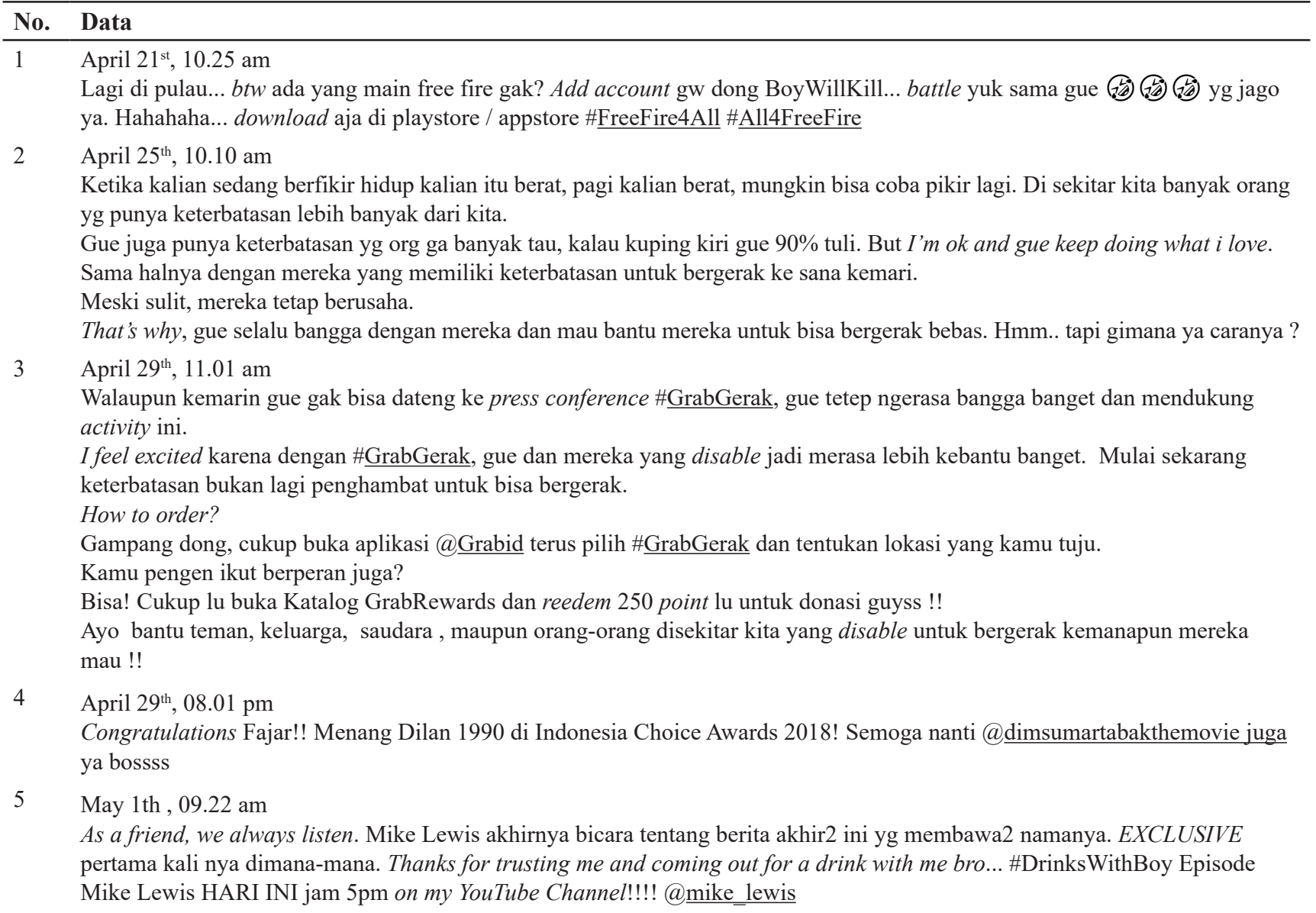

$6 \quad$ May $4^{\text {th }}, 12.01 \mathrm{pm}$

Mau jadi orang pertama yang menikmati novel Dimsum Martabak dengan bonus tanda tangan Ayu Ting Ting dan Boy William, serta key chain foodtruck?

Ayo datang ke launching novel Dimsum Martabak yang akan diadakan pada Sabtu, 5 Mei 2018 pukul 15.00 s.d. 17.00 di Toko

Buku Gunung Agung Margo City Depok.

Segera daftarkan diri kamu ke 0853-5374-1708 (chat WA)

Jangan sampai ketinggalan menyantap Dimsum Martabak yang bikin laper dan baper ya...

\#DimsumMartabak

\#noveldimsummartabak

\#booklaunching

\#launchingdimsummartabak

$7 \quad$ May $7^{\text {th }}, 04.53 \mathrm{pm}$

Setiap shooting \#NebengBoy gue selalu pake GoPro HERO6 dari@urbanrepublicid, makanya hasilnya bisa keren banget! GoPro HERO6 ini juga tahan air, jadi cocok banget buat kalian yg doyan adventure! By the way, udah pada nonton \#NebengBoy terbaru belom!? \#GoProID \#ExperienceDifferent\#EranyaGoPro \#GetOutside\#Urlifestyle

$8 \quad$ May $9^{\text {th }}, 03.07 \mathrm{pm}$

Ngobrol2 gue bareng Craig David dan Hailee Steinfeld udah ada di YouTube. Check it out on @breakoutnetofficial ‘s YouTube channel. Mau request lagu apa buat breakout hari ini?

$9 \quad$ May $12^{\text {th }}, 08.55 \mathrm{pm}$

First time I tried noodles like this..

Gokil banget, baru ini gue nemu mie yang sehat tapi rasanya tetap enak. Boleh juga nih..

Kalau lu udah coba gue jamin lo bakal beli terus kayak gue sekarang.. Haha..

Dari pada makin penasaran dan bikin tambah laper, mending order Fit Mee sekarang juga eksklusif only on Tokopedia.

So, Go and check this out @,tokopedia!!

\#TokopediaCurator \#MulaiAjaDulu

$10 \quad$ May $12^{\text {th }}, 10.01 \mathrm{pm}$

Coba dong guys, tell me which one and kenapa hehehe 


\section{Influencer TT}

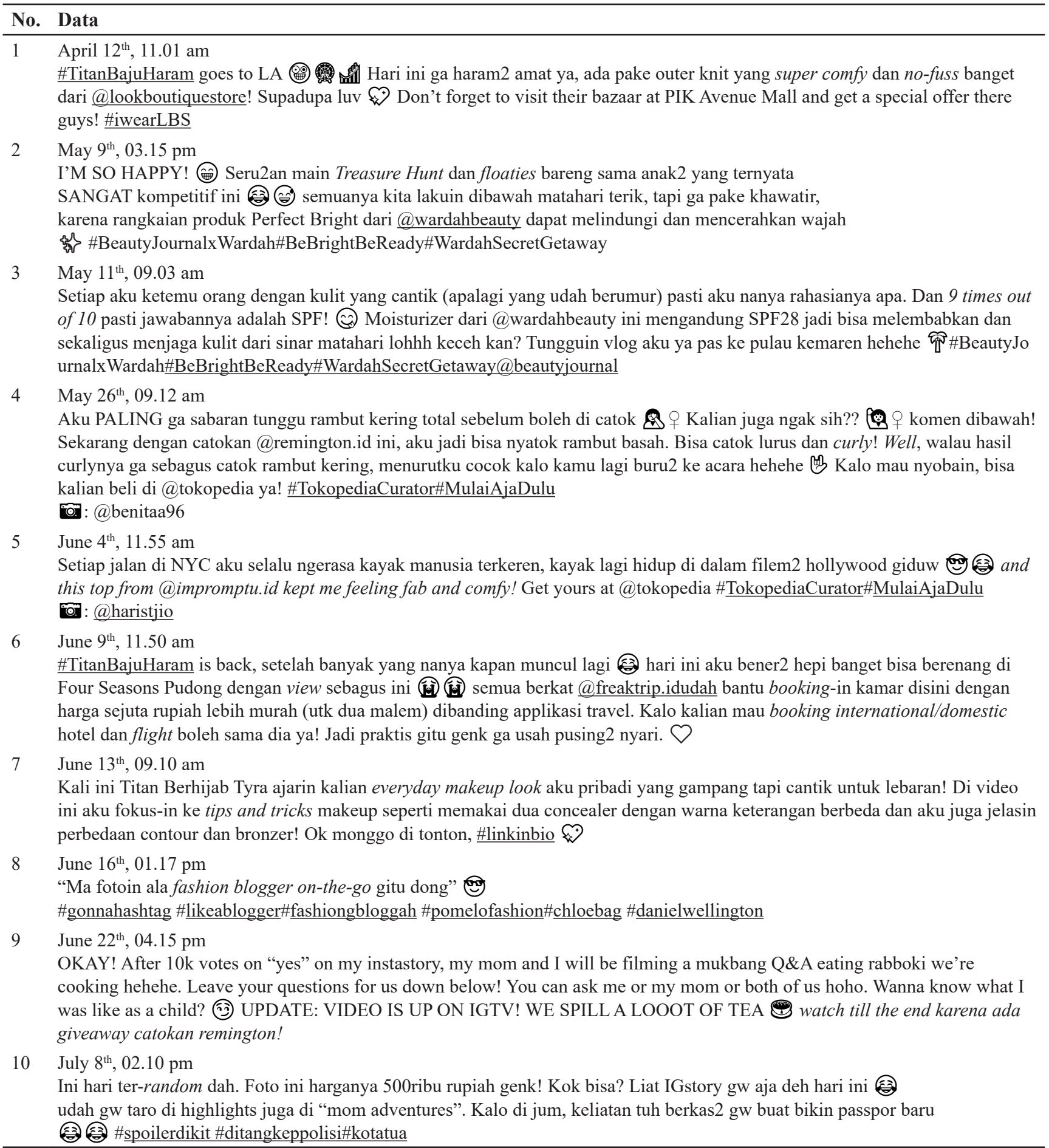

f. You can track the total number of views and which users have viewed your content (www. sproutsocial.com , accessed on May $5^{\text {th }} 2019$ )

\section{Research Method}

This research used qualitative as the method of the research. Bogdan and Taylor (1992) stated that qualitative method is the procedure of the research that it result like the words from the people that observed, and data of result of research like descriptive data. In collecting data, the writer used the following steps: (1) Selection of the influencers in instagram based on their content and how often they use code mixing; (2) Capturing the caption of their posts, or save their videos everytime they use code mixing and (3) finding information from several trusted sources such as (a) Primary sources: instagram from the influencers and their posts and (b) secondary sources: internet from websites, e-books, and e-journals.

\section{DISCUSSION OF RESEARCH FINDINGS}

After observing some influencers in Instagram, the writer decides to take data from influencer BW and TT. The data that are found is qualitative data. This qualitative data that 
are in the form of code mixing can be analysed in content analysis. According to the data analysis, the writer found 30 data of Indonesian English code mixing in Instagram from each influencer. After the data, the writer also explains why and when the influencers use code mixing. First, the writer shows the finding from influencer BW's account, and then influencer TT's. Both influencer's accounts are verified to make the data provided are trusted and worth. The following data are the several examples that can be seen from the table below and the code mixing parts are written in italic.

After collecting the data, the writer also observed influencer BW and TT about the reasons they use code mixing by trying several ways before finally found out the answer.

First, influencer BW stated "Di Indonesia banyak yang bisa ngomong inggris kok. Kita ga kalah sama negara lain bos ku. Harus berkembang dong...You gotta change your mindset. Dont be so bitter about life my friend" (www.liputan6.com, posted on May 16th 2019). There is also his statement from another source that mention “Gue nggak apa-apa dikata-katain, i don't care. Tapi for kids yang mau belajar, kasihan bro. Dan di Indonesia banyak yang bisa ngomong Inggris kok. Kita ga kalah sama negara lain bosku. Harus berkembang dong... You gotta change your mindset. Dont be so bitter about life my friend. God Bless You" (www.suara.com, posted on $16^{\text {th }}$ May 2019).

Similarly with influencer BW, influencer TT stated her response after the writer asked her through direct message in Instagram. Although the writer waited for a long time to get the answer, finally here it is : "haiiii, thanks for thinking of me when $\mathrm{u}$ write your thesis. For me ya aku suka ngomong atau nulis dengan mix Indonesian English gitu because kadang aku suka gak kepikiran bhs indonya dr suatu kata tuh apa, sometimes aku tau nih bhs indonya tp gabisa ucapin with proper way gitu. Trus udah jd kebiasaan juga buatku krn aku grow up dgn lingkungan yg rata2 ngmg English, kayak di sekolah atau family ak. Trus ak juga kuliah di USA which is of course I speak English everyday. Trus ada some sponsors yg request ak untuk post pake English $j g$. But I still love Bahasa indo of course because I was born in this country." Here is the screenshoot of her statements.
From the screen shot above it can be read clearly that the reason of influencer uses code mixing she gets difficulty to find the proper Indonesian's words to be used when she has communication. That is not the single reason to use code mixing. Another reason that she gets habet to using code mixing in her communication and she feels convertible with that habit but anyway she still loves bahasa Indonesia as her mother language.

There are two points to be discussed based on the findings above :

\section{The Reasons that the Influencers Use Code Mixing}

Based on both influencer's statement, the writer can see some reasons why they use code mixing. Is is also suggested by Shabir et al. (2014), that social media influences the youth and females included.

First, they have passions in influencing people to use code mixing, they want people to use English in communication. This is not because they want to show off their english ability, but they want people especially their followers to develop themselves.

Second, the influencers do not want people to look down in other language. It can be proved by influencer BW's statement "Dan di Indonesia banyak yang bisa ngomong Inggris kok. Kita ga kalah sama negara lain bosku. Harus berkembang dong... You gotta change your mindset. Dont be so bitter about life my friend."

Then, some of the influencer's sponsor and endorsement want the influencers to post and update use English or mix Indonesian English. It can be because the sponsors and brands notice that many people especially the influencers' followers think that the post in mix language is more interesting and can attract people more than posts in Bahasa Indonesia only. And this is also because some brands are international brands so if the influencers post in English, not only Indonesian but people from other countries can understand.
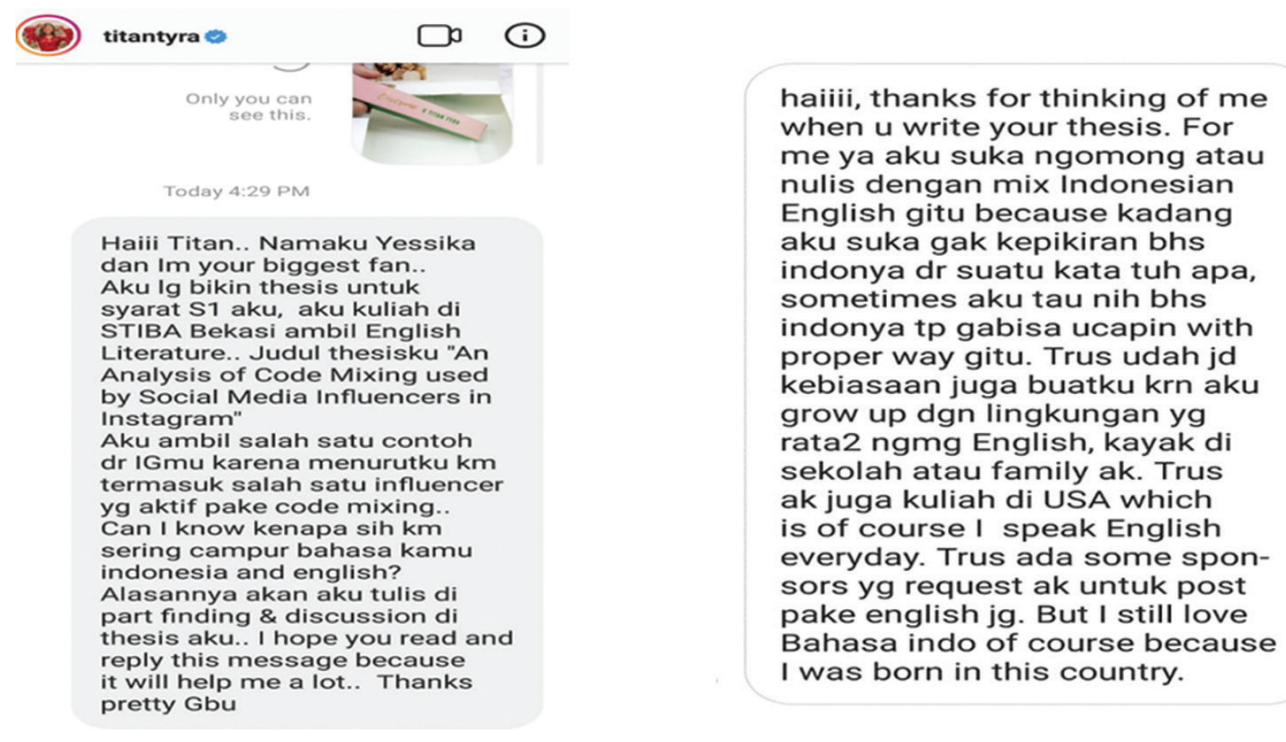


\section{When the Influencers Use Code Mixing}

Out of 30 post that the writer took from Influencer BW Instagram, the time range are in 7 until 11 a.m. total 15 post, 12 until 6 p.m. total 9 post, and 7 until 10 pm total 6 post. The purpose of his post are 10 posts for endorsement, 8 posts for promotion, and 12 posts for personal purpose. The percentage of this result is influencer BW's posts are $40 \%$ for his personal purpose, $33 \%$ for endorsement, and 27\% for promotion.

The different result appears from influencer TT which $70 \%$ of her posts are for endorsement purpose. The rest are $23 \%$ for promotion and only $7 \%$ for personal purpose. This percentage is specifically divided to 21 posts for endorsement, 7 posts for promotion, and 2 posts for personal purpose. She post the statements in time range 07 until 11 a.m. total 12 posts, 12 until 6 p.m. total 17 posts, and 7 until 10 p.m. total 1 post.

\section{CONCLUSION}

Code mixing is mainly found in informal interactions, it occurs when the conversants use both language together, its term refers to all cases about lexical and grammatical features, and it is an act of switching languages.

In influencer BW and TT Instagram, it clearly explains to us that both of them are actively using code mixing. They have their own reasons about why and when they use code mixing. So, there are some points that can be concluded from the data found : (1) The influencers use code mixing because they want Indonesian people to develop themselves by mastering English language. English has become one of international language that is always used for communication among people from different countries, and so many also use it for business. They want to give example to people, especially their followers that English can be fun and everyone can speak English. This reason is in line with one of Chukwuere's research findings that social media can lead to change in social and personal lifestyle both academically and off-academic (Chukwuere and Chuckwuere (2017); (2) The influencers use code mixing because it has been a habit for them. The habit is because they grow up with family and friends who speaks English or they went to international school and college. Because of this habit, they find difficulty when they have to speak completely in Bahasa Indonesia so they decide to speak it out in English; (3) The influencers use code mixing because some sponsors and brands that endorse them want them to post in fully English or mix Indonesia English; and (4) The Influencers post in certain time because that is active time for them and their followers online in Instagram. If they post in certain time, the followers will more actively give feedback to their post. It can be concluded that the use of code-mixing by the influencers arouse the followers' motivation to study English language and through social media, it can be the way to practice English for the followers.

\section{REFERENCES}

Akram, W \& Kumar, W. (2017). A Study on Positive and Negative Effects of Social Media on Society. International Journal of Computer Sciences and Engineering. Vol.5, i.10.

Bloch, B. \& Trager. L.C. (1942). Linguistic Analysis. USA: Linguistic Society of America

Bogdan, R.C. \& J.Taylor, S. (1992). Introduction to Qualitative.

Chaer, A. \& Agustina, L. (2004). Sosiolinguistik. Jakarta: Rineka Cipta.

Chukwuere, J.E. and Chuckwuere, P.C. (2017). The Impact of Social Media on Social Lifestyle: A Case Study of University Female Students. Journal of Gender \& Behaviour. ISSN:1596-9231.

Dr. Shaghi, A. (2013). Introduction to Language 1. Zabid-College of Education.

Hoffman, C. (1991). An Introduction to Billingualism. New York: Longman.

Kim, E.(2006). Reasons and Motivations for Code-Mixing and Code-Switching. TESOL Journal.

Leech, G. (1974). Five Functions of Language.

Lowisz, S. (2014). The Influence of Social Media on Today's Culture. stevelowisz.com/wp .../02/TheInfluence-of-Social-media-inTodays-Culture-wp.pdf

Lucas, C. (1990). Sign Language Research: Theoretical Issues. Washington DC: Gallaudet University Press

Muysken, P. (2000). Billingual Speech. Cambridge: Cambridge University Press

Muysken, P. (2000). Typology of Code Mixing. Cambridge: Cambridge University Press

Nababan. (1984). Sosiolinguistik : Suatu Pengantar. Jakarta: Gramedia.

Safko, L. and Brake, D. K., (2009). The social media bible: tactics, tools, and strategies for business success. Hoboken, NJ: John Wiley \& Sons.

Shabir, G., Hameed, Y. M. Y., Safdar, G., \& Gilani, S. M. F. S. (2014). The Impact of Social Media on Youth: A Case Study of Bahawalpur City. Asian Journal of Social Sciences and Humanities, 3(4), 132-151.

Siregar. (1996). Code Alternation in Billingual Speech Behaviour. Medan : USU

Suwito. (1983). Pengantar Awal Sosiolinguistik: Teori dan Problema. Surakarta : Offset Solo.

Sweet, H. (2007). The History of Language. US: Kessinger Publishing

Walter, E. \& Gioglio, J. (2014). The Power of Visual Storytelling: How to use Visuals, Videos, and Social Media to Market Your Brand. USA : McGraw Hill Professional.

Wardhaugh, R. (1986). An Introduction to Sociolinguistics. New York: Brasil Blackwell.

Wardhaugh, R. (2011). An Introduction to Sociolinguistics. Oxford: Wiley-Blackwell

Xiang, Z. and Gretzel, U., (2010). Role of social media in online travel information search. Tourism Management. 


\section{Internet Sources}

www.hootsuite.com , accessed on May $3^{\text {rd }} 2019$

www.buffer.com , accessed on May $3^{\text {rd }} 2019$

www.lifewire.com, accessed on August 27 2019

www.techtarget.com , accessed on August $27^{\text {th }} 2019$

www.whatiswechat.com, accessed on August 27 2019

www.techterms.com, accessed on August 27 2019

www.linkinfluence.com , accessed on August 27 2019

www.techopedia.com, accessed on August 27 2019

www.digitalzone.in, accessed on August 27 2019

www.webwise.ie, accessed on August $27^{\text {th }} 2019$

www.lifewire.com, accessed on May $5^{\text {th }} 2019$

www.sproutsocial.com, accessed on May $5^{\text {th }} 2019$ 